DIE REG VAN DIE HOMOSEKSUELE OUER OM BEHEER EN TOESIG OOR 'N KIND TE VERKRY IN DIE LIG VAN DIE BEPALINGS VAN DIE GRONDWET

ISSN 1727-3781

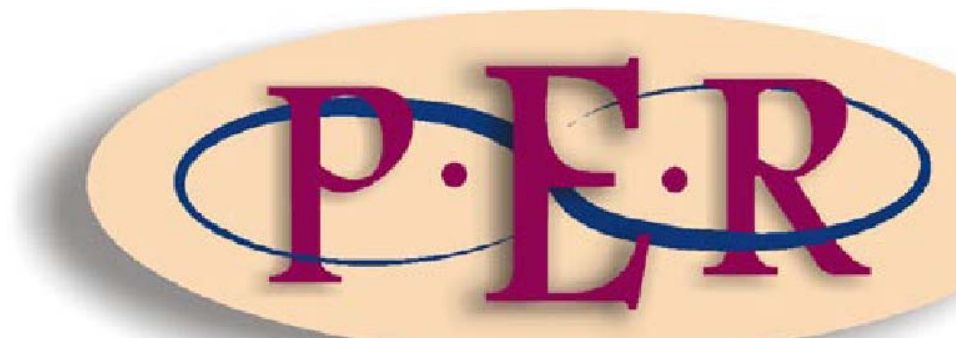

1999 VOLUME 2 No 2 


\section{Die reg van die homoseksuele ouer om beheer en toesig oor 'n kind te verkry in die lig van die bepalings van die Grondwet}

\section{Antoinette Kotze}

Die problematiek ten opsigte van die reg van 'n homoseksuele ${ }^{2}$ ouer om beheer en toesig oor 'n kind te verkry, is tweeledig van aard: die aard en omvang van beheer- en toesiggeskille sowel as die kwessie van diskriminasie op grond van seksuele oriëntasie is ter sprake. Homoseksuele oriëntasie is emosioneel en kontroversieel, so veel te meer as dit gepaard gaan met beheer- en toesig-geskille. In hierdie verband is die grondwetlike beskerming wat aan menseregte verleen word, ${ }^{3}$ sowel as die bepalings in die Grondwet waarin grondwetlike waardes verreken word, ${ }^{4}$ van belang. Die inhoud van sodanige bepalings hou direkte gevolge vir beheer- en toesig-geskille en homoseksuele ouerskap in. Sedert die inwerkingtreding van die Grondwet van die Republiek van Suid-Afrika 200 van $1993^{5}$ het geen Suid-Afrikaanse hof nog uitspraak in hierdie verband gegee nie. ${ }^{6}$ Die doel van hierdie bespreking is nie uitsluitlik om uitgekristalliseerde regsbeginsels weer te gee nie, maar om in die lig van die bepalings van die Grondwet 'n geïntegreerde beeld van die regsposisie van die homoseksuele ouer met betrekking tot beheer en toesig aangeleenthede te skep. Daar word gefokus op die interpretasie en toepassing van die bepalings in die Grondwet met betrekking tot die posisie van die kind en seksuele

1 Hierdie bydrae vorm deel van 'n projek oor grondwetlike waardes binne die navorsingsfokusarea, Ontwikkeling in die Suid-Afrikaanse Regstaat, van die Fakulteit Regte, $\mathrm{PU}$ vir CHO.

2 Die begrip "homoseksualiteit" verwys deurgaans in die teks na sowel gay- as lesbiese verhoudings. Cameron 1993 SALJ 452 definieer seksuele oriëntasie met verwysing na erotiese aantrekking: in die geval van heteroseksuele persone is dit lede van die teenoorgestelde geslag en in die geval van homoseksuele persone is dit lede van dieselfde geslag. Hy merk verder op dat die vraag na ' $n$ definisie nie net terminologies, maar ook polities en teoreties van aard is, aangesien die opkoms van homoseksuele identiteit as politieke feit 'n onlangse verskynsel is.

3 Hoofstuk 2: Handves van Regte, Grondwet van die Republiek van Suid-Afrika 108 van 1996 (hierna genoem Grondwet). 4 Die Aanhef, a 1, 7(1), 36(1) en 39(1). 5 Hierna genoem interim Grondwet. 6 Die bepalings wat geld na die inwerkingtreding van die Grondwet geld ook vir die tydperk sedert die inwerkingtreding van die interim Grondwet tot en met die inwerkingtreding van die Grondwet, tensy daar andersluidende bepalings is, in welke geval dit spesifiek aangetoon sal word. 
oriëntasie, in die lig van die waardes soos uiteengesit in die Grondwet. Sodanige resultate word vervolgens in verband met die reg van die homoseksuele ouer om beheer en toesig oor ' $n$ kind te verkry, gebring. Aan die hand van die bepalings van die Grondwet, regspraak en regsvergelykende perspektiewe word riglyne voorgestel ten einde 'n outochtone SuidAfrikaanse verwysingsraamwerk daar te stel, gerig op die oplossing van bogenoemde problematiek.

\section{Die reg van die homoseksuele ouer om beheer en toesig oor 'n kind te verkry}

Die reg van 'n homoseksuele ouer om beheer en toesig oor 'n kind te verkry spreek in wese twee kwessies aan, naamlik beheer en toesig, daarby inbegrepe die beste belang van die kind, $^{8}$ en tweedens seksuele oriëntasie en spesifiek homoseksuele oriëntasie.

7 Hoffman en Pincus Custody 5 definieer beheer en toesig as die gebeurtenis of deel van voogdy waar die ouer in wie beheer en toesig gesetel is, bevoeg is om die kind in sy/haar bewaring te hou, beheer uit te oefen oor die kind se daaglikse lewe, besluite te neem rakende die kind se opvoeding en opleiding, ook ten opsigte van die religieuse sy, en mag bepaal met wie die kind mag assosieer, al dan nie. Barnard, Cronjé en Olivier Persone- en Familiereg 354 definieer beheer en toesig as die bevoegdheid van ' $n$ persoon om die werklike fisiese "besit" van die kind te hê, om saam met die kind te leef en om hom/haar op te pas en by te staan in sy/haar daaglikse handel en wandel.

8 Hierdie beginsel is deurslaggewend by die toekenning van beheer en toesig aan ' $n$ persoon, veral soos blyk uit regspraak en a 28(2) van die Grondwet. Märtens v Märtens 19914 SA 287 (T); Van der Linde 1995 Codicillus 63-64. In McCall v McCall 19943 SA 201 (K) waarsku die hof dat die lys van faktore genoem (die sogenaamde kontrolelys) blote kriteria is by die bepaling van welke ouer geskik sal wees om beheer en toesig te verky. Daar word betoog dat die uiteensetting van so 'n lys faktore gesonde regsontwikkeling is en dat verpligte oorweging van sodanige faktore statutêr opgeneem behoort te word. Robinson 1995 THRHR 476-477 meen dat die hof geen aanduiding gee op welke wyse daar met die lys van faktore omgegaan moet word nie. Hy wys daarop dat die tabulering van sodanige faktore in pas is met die "statutory checklist" wat in die Engelse Children Act van 1989 opgeneem is. Hy argumenteer voorts dat slegs die mees wesenlike aspekte deur 'n kontrolelys aangespreek behoort te word en dat die hof steeds ' $n$ diskresie moet hê om enige ander relevante oorweging in aanmerking te neem. Hy maak verder die submissie dat dit in die beste belang van die kind is dat a 6(3) van die Wet op Egskeiding 70 van 1979, gelees met die bepalings van die Wet op Bemiddeling in Sekere Egskeidingsgedinge 24 van 1987, gewysig moet word om voorsiening te maak vir so 'n kontrolelys. Sien ook Robinson 1993 TRW 41-66 in hierdie verband. Daar kan met NöthlingSlabbert 1995 CILSA 367 saamgestem word dat die beste belang van die kind 'n vraag van interpretasie van verkeie verwante faktore en omstandighede is. Sien Palmer 1996 Acta Juridica 98113 met betrekking tot 'n oorsig van regspraak tot en met 1995 in hierdie verband. 


\subsection{Van Rooyen v Van Rooyen ${ }^{9}$}

\subsubsection{Feite}

In die pre-grondwetlike bedeling ${ }^{10}$ het die Witwatersrandse Plaaslike Afdeling uitspraak gegee ten opsigte van die toekenning van toegangsregte aan 'n homoseksuele ouer. Die verband tussen beheer en toesig en toegang ondersteun die relevansie van hierdie gewysde vir die kwessie onder bespreking.

In casu het die applikant (die moeder van die kinders) aansoek gedoen om haar toegangsregte ten opsigte van haar twee minderjarige kinders, 'n seun van elf en 'n half jaar oud en 'n dogter van nege en 'n half jaar oud, te definieer. Met die egskeiding van die applikant en die respondent ses jaar tevore, is beheer en toesig aan die respondent toegeken en is daar wyd omskrewe toegangsregte aan die applikant toegeken. ${ }^{11}$ In 1992 het die respondent se houding drasties verander ten opsigte van die toegangsregte toegeken aan die applikant weens redes onbekend aan die hof. ${ }^{12}$ Hierdie veranderde houding van die respondent gee aanleiding tot die applikant se aansoek.

In sy uitspraak is regter Flemming deurentyd bewus van die tweeledige rol van die hof, naamlik geskilbeslegter en oppervoog van die kinders. In casu is die vermoë en geskiktheid van die applikant om as moeder op te tree nie in geskil nie, maar is die lesbiese verhouding waarby sy betrokke is, die draaipunt. In hierdie verhouding het die

919942 SA 325 (W); Brits 1994 THRHR 710-712; Bonthuys 1994 Stell LR 298-306; De Vos 1994 SALJ 687-694; Lind 1995 SALJ 488-489; Steyn 1998 TSAR 114.

10 Die bedeling voor die inwerkingtreding van die interim Grondwet.

11 326G-H.

12 327A-D.

13 326A-C, 326F-G, 327F-G. Vgl Brits 1994 THRHR 710. Volgens die Romeins-Hollandse reg is die hooggeregshof die oppervoog van alle kinders. As oppervoog kan die hof die trefwydte van redelike toegang deur die ouer wat nie beheer en toesig oor die kinders het nie, bepaal. Die hof moet gelei word deur die inagneming van die beste belang van die kind (sien September v Karriem 19593 SA 687 (K) 689; Segal v Segal 19714 SA 317 (K) 324; S v S 19932 SA 200 (W) 208). 
applikant 'n huis en slaapkamer met haar vriendin gedeel. ${ }^{14}$ Teen hierdie agtergrond moes die hof 'n toegangsbevel formuleer wat in die beste belang van die kinders is. Die hof steun in sy uitspraak op die bevindings van die gesinsadvokaat en twee sielkundiges. Die gesinsadvokaat poog om aan te toon dat die kwessie van seksuele oriëntasie irrelevant is, terwyl die sielkundiges die beskerming van die kinders teen hul moeder se lewenstyl propageer. Die bevindings van die sielkundiges het die grootste impak op die hof gehad. Volgens die sielkundiges is daar geen fout met die toekenning van oornagtoegangsregte aan die applikant nie, maar wat wel problematies is, is die lesbiese verhouding waarby die applikant betrokke is, aangesien dit verwarrende tekens ${ }^{15}$ aan die kinders deurgee. ${ }^{16}$ Regter Flemming is van mening dat homoseksualiteit per se abnormaal is. Om die kinders bloot te stel aan hul moeder se lesbiese verhouding, sal skadelik wees, alhoewel die littekens hiervan eers later in die kinders se lewens te bespeur sal wees. ${ }^{18}$ Die hof tref gevolglik onderskeid tussen naweekbesoeke en langer besoeke gedurende skoolvakansies. Die bevel wat die hof maak skryf voor dat die applikant en haar vriendin nie dieselfde slaapkamer gedurende naweke mag deel nie en gedurende skoolvakansies nie dieselfde woning nie. ${ }^{19}$

$14326 \mathrm{H}-\mathrm{I}$.

15 Op 329I - 330B lig die hof toe wat die sogenaamde verwarrende tekens is: "The signals are given by the fact that the children know that, contrary to what they should be taught as normal or what they should be guided to as to be correct (that it is a male and female who share a bed), one finds two females doing this... It is detrimental to the child because it is the wrong signal...". Brits 1994 THRHR 711 merk op dat die vraag hier is of die gedrag van die applikant en haar metgesel deur die hof gesien moet word as van ' $n$ algemeen verwarrende aard en of die hof net verwys na die moontlikheid van benadeling van die seksuele ontwikkeling van die kinders. Dit moet beoordeel word teen die agtergrond van die hof se mening dat die wedersydse band tussen die moeder en haar kinders verstewig behoort te word (326C-D). Hy kom tot die gevolgtrekking dat in die konteks van die aansoek "verwarrende gedrag" net "seksueel verwarrend" beteken.

16 328C-D.

17 329A-B.

$18328 \mathrm{H}-\mathrm{I}$.

19 331F-I. 


\subsubsection{Kritiek}

Punte van kritiek teen die Van Rooyen-beslissing sluit in die eerste plek in dat die hof nie daarin slaag om die relevansie van die gesinsadvokaat se bevinding met betrekking tot die morele verwytbaarheid en nie-geestesgebrekkige aard van homoseksualiteit, raak te sien nie. $^{20}$ Onlangse navorsing toon dat die geestesgesondheid van homoseksuele persone in alle opsigte vergelykbaar is met dié van heteroseksuele persone. Wanneer daar wel sprake van emosionele onstabiliteit is, gaan dit gewoonlik gepaard met angsaanvalle weens verwerping op grond van die persoon se seksuele oriëntasie deur die samelewing. Sodanige onstabiliteit kan egter vergelyk word met soortgelyke verskyningsvorme van emosionele onstabiliteit by heteroseksuele persone.

Die hof vel 'n morele oordeel aangaande die normaliteit en abnormaliteit van homoseksualiteit. ${ }^{22}$ Vogens Brits ${ }^{23}$ het die hof nog nie die mite afgeskud wat homoseksuele persone tipeer as primêr seksueel promiskue wesens wat voortdurend op die uitkyk is vir nuwe seksmaats nie, terwyl homoseksualiteit in die moderne tyd beskou word as 'n wisselvoorkoms van seksuele uitlewing en nie as afwykende gedrag nie. ${ }^{24}$ Die standpunt dat homoseksualiteit 'n natuurlike seksuele variant is wat nie aan enige patalogie gekoppel kan word nie, is reeds in 1973 deur die American Psychological

20 De Vos 1994 SALJ 688.

21 Clark 1998 CILSA 302; Mosikatsana 1996 Acta Juridica 122-123.

22 De Vos 1994 SALJ 689.

23 Brits 1994 THRHR 711.

24 Visser 1995 THRHR 705 merk op: "Dit is gelukkig steeds vir die meeste redelike mense werklikheidsvreemd om homoseksualiteit, lesbianisme en biseksualiteit as 'normaal' te aanvaar met al die gevolge wat sodanige erkenning van abnormaliteit inhou. Hopelik sal gesonde verstand ook regtens seëvier sodat die grondwetlike verbod op onbillike diskriminasie teen mense op grond van hul seksuele georiënteerdheid so uitgelê en toegepas word dat dit nie die wese van die bestaande huweliksreg aantas nie." Daar word saam met De Vos 1996 THRHR 305 gestem dat hierdie onderskeid klaarblyklik gevorm is deur die skrywer se godsdienstige en morele denkraamwerk. Godsdienstige en morele vooroordele is egter in stryd met algemeen aanvaarde opvattings binne die regswetenskaplike kader. 
Association in 'n mosie aangeneem en blyk ook uit die standpunte van verskeie skrywers en uit regspraak.

Derdens stel die hof die applikant voor 'n keuse tussen lesbianisme en toegang tot haar kinders. ${ }^{26}$ Volgens die hof is die gelyktydige uitoefening van lesbianisme en toegang tot haar kinders nie moontlik nie. Die vraag is of sodanige keuse nie per se diskriminasie daarstel nie.

Die hof aanvaar skynbaar nie die moontlikheid dat daar in casu van 'n "gesin" gepraat kan word nie. Die vraag is welke elemente aanwesig moet wees om 'n gesin daar te stel. Die aanwesigheid van 'n wye verskeidendheid van gesinstrukture in die Suid-Afrikaanse samelewing bemoeilik die beantwoording van hierdie vraag. Eerste wêreldlande word tans gekenmerk deur die ontploffing van die enkelouergesin as gesinstruktuur. Die erkenning van 'n verskeidenheid van gesinsvorme gee aanleiding tot die sosiale aanvaarding van verskille. $^{27}$ Daar moet ook oorweeg word of hierdie stabiele en liefdevolle omgewing nie meer bevorderlik is vir die welstand van die kinders, as die las deur die hof opgelê by wyse van gekwalifiseerde bevele, nie.

Vyfdens bestaan daar geen sielkundige - of regsgrondslag vir die hofbevel nie. Alhoewel ' $n$ kind grootliks die gedrag van ouers en ander persone in sy/haar omgewing naboots, bestaan daar egter 'n verskeidenheid van stimuli vanuit verskillende oorde wat op die jeugdige inwerk, sodat 'n enkele persoon se gedrag nie deurslaggewend is nie. Daar bestaan geen wetenskaplike - of sielkundige bewyse dat homoseksualiteit by wyse

25 Cameron 1993 SALJ 458; De Vos 1996 THRHR 305; S v H 19932 SAS 545 (K) 548 waar regter Ackermann kommentaar lewer op vorige hofuitsprake: "In my respectful view the use of the word 'normal' in this context is unfortunate, as it might suggest a prejudgment of much current psychological and sociological opinion which is critical of various conventions and assumptions regarding human sexuality."

26 Brits 1994 THRHR 711; De Vos 1994 SALJ 689.

27 Clark 1998 CILSA 288; Lind 1995 SALJ 482-485; Steyn 1998 TSAR 105-113.

28 Brits 1994 THRHR 711-712; Van Rooyen v Van Rooyen 19942 SA 325 (W) op 326I: die applikant leef in ' $n$ situasie wat sy as ' $n$ "stable and secure environment for the minor children" beskryf.

29 331H; Clark 1998 CILSA 301; Mosikatsana 1996 Acta Juridica 124-125. 
van nabootsing aangeleer word nie. Skrywers is van mening dat verleiding wel 'n rol kan speel by die ontstaan van homoseksualiteit indien daar reeds ' $n$ neiging daartoe by sodanige kind bestaan. ${ }^{30}$ Dit is egter opmerklik dat daar 'n groot hoeveelheid homoseksuele persone is wat juis heteroseksuele ouers het.

Navorsing toon dat by die bepaling van die beste belang van die kind in beheer- en toesiggeskille daar 'n verskil in benadering is tussen regslui en sielkundiges. Beide regslui en sielkundiges heg waarde aan die morele karakter van die onderskeie ouers. Dit is egter 'n praktyksgewoonte om die kind nie in die beheer en toesig van die ouer te plaas wat egbreuk gepleeg het, en sodoende aanleiding gee tot 'n egskeiding, nie. Die bevindings van sielkundiges toon egter dat 'n huis waarin 'n kind ongelukkig is, groter skade aanrig as 'n gebroke huis. Terwyl die howe geneig is om beheer en toesig toe te ken aan die ouer in wie se tydelike beheer en toesig die kind geplaas word, dui navorsing daarop dat dit in die beste belang van die kind is om hom/haar in die ouer met wie hy/sy ' $n$ sterk sielkundige band het, se beheer en toesig te plaas. Dieselfde geld ten opsigte van howe se geneigdheid om kinders eerder in die moeder se beheer en toesig te plaas. Howe heg min waarde aan die wense en voorkeure van die kind. In 8 uit 100 sake is kinders deur die onderskeie voorsittende beamptes ondervra in hierdie verband. Om 'n verskeidenheid van redes glo sielkundiges dat die wense en voorkeure van 'n kind van kardinale belang is by die bepaling van die beste belang van die kind. Vervolgens is howe se geneigdheid om kinders in die beheer en toesig van ouers wat hertrou te plaas, ook vir kritiek vatbaar. Die twee ouerhuisgesin-benadering hou nie rekening met die emosionele spanning wat hertroue op kinders plaas nie.

Daar word met Bonthuys ${ }^{33}$ saamgestem dat die kernprobleem van die Van Rooyenbeslissing geleë is in die formulering van die beste belang van die kinders. Algemeen

Brits 1994 THRHR 712.

Bonthuys 1994 Stell LR 304-305.

Lambiase en Cumes 1987 SALJ 705.

33 Bonthuys 1994 Stell LR 299, 305. 
aanvaarde en moderne opvattings ten opsigte van die welstand van kinders word buite rekening gelaat. Alhoewel dit die hof se plig is om te verwys na heersende morele en sosiale standaarde, moet dit geskied in die lig van 'n juridiese en wetenskaplike fundering en nie op grond van populêre vooroordele nie. Die hof roem daarop dat die beslissing gegrond is op die beste belang van die kind, tog is dit opmerklik in die uitspraak dat die oorwegende faktor die seksuele oriëntasie van die moeder is.

Die Van Rooyen-beslissing ondersteun Cameron ${ }^{34}$ se standpunt dat die reg hom veel meer met homoseksuele optrede besig hou as met homoseksuele identiteit. Hy propageer die standpunt dat diskriminasie op grond van homoseksualiteit verder strek as diskriminasie gerig teen die homoseksueel self en die homoseksuele daad wat hy/sy beoefen, maar dat daar ook gediskrimineer word teen persone wat homoseksualiteit as natuurlike seksuele variant beskou, aangesien sodanige persone geag word meer geneig te wees om homoseksuele dade te beoefen, alhoewel hy/sy inderdaad heteroseksueel is.

\section{2 'n Grondwetlike analise}

Onderliggend aan die reg van die homoseksuele ouer om beheer en toesig oor 'n kind te verkry, is 'n aantal regte wat in die Handves van Regte ${ }^{35}$ in die Grondwet vervat is. Veral van belang is die reg op gelykheid ${ }^{36}$ en die bepaling waarin die regte van kinders vervat is. Hierdie bepalings moet in samehang met die onderskeie grondwetlike waardes ${ }^{38}$ en die beperkingsklousule ${ }^{39}$ uitgelê word.

Die Grondwet bevat ' $n$ reeks waardes aan die hand waarvan die bepalings van die Grondwet en ander regsnorme uitgelê moet word, te wete menswaardigheid, gelykheid, vryheid,

34 Cameron 1993 SALJ 452.

35 Hfst 2.

36 A 9.

37 A 28.

38 Die Aanhef, a 1, 7(1), 36(1) en 39(1).

39 A 36. 
demokrasie, oppergesag van die Grondwet, heerskappy van die reg, nie-rassisme en nieseksisme. Alhoewel die waardes nie absolute gelding het en opsigself regte daarstel nie, moet daar kennis van geneem word by die uitleg van die onderskeie fundamentele regte en ander regsnorme.

Die vraag na die grondslag vir die grondwetlike beskerming van die reg op gelykheid en spesifiek daarby inbegrepe gelykheid met betrekking tot seksuele oriëntasie, word aan die hand van twee argumente beredeneer. ${ }^{41}$ Die eerste argument lui dat die erkenning van die reg op privaatheid ${ }^{42}$ aanleiding sal gee tot die dekriminalisasie van homoseksuele optrede in die private sfeer. Daar word aangevoer dat die reg van 'n individu om deel te neem aan intieme verhoudings in die privaatheid van sy/haar huis, juis die kern is waarom grondwetlike beskerming ten opsigte van gelykheid draai. Die leemte wat sodanige argument laat, is dat slegs die strafbare verbod op homoseksualiteit uitgewis word. Homoseksualiteit bly steeds skandelik in die oë van die gemeenskap aangesien daar slegs voorsiening gemaak word vir die uitleef van homoseksualiteit in die privaatheid van die slaapkamer. Hierdie argument het geen rehabiliterende uitwerking op die denkraamwerk en vooroordele van die samelewing nie en in effek is dit steeds diskriminerend.

Die tweede argument ondersteun die gedagte dat menswaardigheid en gelykheid as grondwetlike waardes die fondament lê vir die grondwetlike beskerming van die reg op gelykheid. ${ }^{43}$ Hierdie argument bied 'n veel sterker basis vir die beskerming en erkenning van die bestaan van gelyke seksuele oriëntasie. Die erkenning van 'n individu se menswaardigheid en gelykheid as inherente eienskappe, ${ }^{44}$ is die enigste argument wat reg laat geskied aan die onhoudbaarheid van diskriminasie op grond van homoseksuele oriëntasie. Sodoende bestaan daar geen verskil, hetsy moreel of juridies, tussen

40 A 39(1)(a); Henderson 1997 SALJ 550-552; Steyn 1998 TSAR 100, 102.

41 Cameron 1993 SALJ 463-465.

42 A 14.

43 S v Makwanyane 19956 BCLR 665 (KH) par [328]; The National Coalition for Gay and Lesbian Equality $v$ The Minister of Justice 19981 BCLR 1517 (KH) par [120]. 
heteroseksuele -, homoseksuele - en biseksuele persone nie. Hierdie argument ondersteun die gedagtegang dat:

- $\quad$ seksuele oriëntasie en die uitdrukking daarvan opsigself nie sosiale sensuur regverdig nie (wat ookal die individu se morele oortuigings is);

- $\quad$ homoseksuele oriëntasie nie 'n siekte of versteuring is nie; en

- $\quad$ seksuele oriëntasie nie 'n rol behoort te speel by die toekenning van geleenthede of in die voorsiening van dienste of goedere nie.

Derhalwe moet die inhoud van artikel 9 van die Grondwet vir die doeleindes van hierdie bespreking ondersoek word. Artikel 9 lui soos volg:

(1) Elkeen is gelyk voor die reg en het die reg op gelyke beskerming van die reg.

(2) Gelykheid sluit die volle en gelyke genieting van alle regte en vryhede in. Ten einde die bereiking van gelykheid te bevorder, kan wetgewende en ander maatreëls getref word wat ontwerp is vir die beskerming of ontwikkeling van persone, of kategorieë persone, wat deur onbillike diskriminasie benadeel is.

(3) Die staat mag nie regstreeks of onregstreeks onbillik teen iemand diskrimineer op een of meer gronde nie, met inbegrip van ras, herkoms, kleur, seksuele georiënteerdheid, ouderdom, gestremdheid, godsdiens, gewete, oortuiging, kultuur, taal en geboorte.

(4) Geen persoon mag regstreeks of onregstreeks onbillik teen iemand op een of meer gronde ingevolge subartikel (3) diskrimineer nie. Nasionale wetgewing moet verorden word om onbillike diskriminasie te voorkom of te belet.

(5) Diskriminasie op een of meer van die gronde in subartikel (3) vermeld, is onbillik, tensy daar vasgestel word dat die diskriminasie billik is.

44 The National Coalition for Gay and Lesbian Equality v The Minister of Justice 19981 BCLR 1517 (KH) $\operatorname{par}[120]$. 
Subartikels (3) en (4) maak melding van "onbillike diskriminasie". Die vraag is welke optrede in "onbillike diskriminasie" sal resulteer. Die Konstitusionele Hof het in Harksen $v$ Lane $^{45}$ 'n veelfasige toets aangewend in hierdie verband. Ter aanvang moet vasgestel word of daar sprake van differensiasie tussen persone of kategorieë van persone is. Vervolgens moet die gevolg van sodanige differensiasie vasgestel word. Dit word gedoen aan die hand van die aanwesigheid van diskriminasie. Indien daar differensiasie ten opsigte van een van die gronde soos uiteengesit in subartikel (3) is, is daar sprake van diskriminasie. Indien die beweerde diskriminasie nie op sterkte van een van die spesifieke gronde is nie, word die afwesigheid van diskriminasie vermoed. In sodanige geval word daar ondersoek ingestel na die objektiewe moontlikheid van die aantasting van die klaer se menswaardigheid. By die aanwesigheid van diskriminasie moet verdere ondersoek na die onbillikheid daarvan ingestel word. Diskriminasie op grond van een van die gronde soos uiteengesit in subartikel (3), word geag onbillikheid daar te stel. Waar die diskriminasie buite die grense van subartikel (3) val, sal die klaer onbillikheid moet bewys met verwysing na die invloed van die diskriminasie op sy/haar omstandighede. By die aanwesigheid van onbillike diskriminasie moet ondersoek ingestel word na die regverdiging van sodanige diskriminasie deur die werking van die beperkingsklousule.

Artikel 36 lui soos volg:

(1) Die regte in die Handves van Regte kan slegs kragtens 'n algemeen geldende regsvoorskrif beperk word in die mate waarin die beperking redelik en regverdigbaar is in 'n oop en demokratiese

45199711 BCLR $1481(\mathrm{KH})$. 
samelewing gebaseer op menswaardigheid, gelykheid en vryheid met inagneming van alle tersaaklike faktore, met inbegrip van -

(a) die aard van die reg;

(b) die aard en omvang van die beperking;

(c) die belangrikheid van die doel van die beperking;

(d) die verband tussen die beperking en die doel daarvan; en

(e) 'n minder beperkende wyse om die doel te bereik.

(2) Behalwe soos in subartikel (1) of in enige ander bepaling van die Grondwet bepaal, mag geen regsvoorskrif enige reg wat in die Handves van Regte verskans is, beperk nie.

Die regte soos vervat in die Handves van Regte het nie absolute gelding nie. Alhoewel die inhoud van artikel 36(1) verskil van die inhoud van die beperkingsklousule, artikel 33, van die interim Grondwet, word beide artikels se werking gekenmerk deur die prosedure soos beskryf in $S$ v Makwanyane:

"... weighing up of competing values, and ultimately an assessment based on proportionality ... which calls for the balancing of different interests."

'n Proporsonaliteitstoets word dus voorgestaan. Faktore wat in ag geneem moet word by die afweeg van regte, sluit die volgende in:

- $\quad$ die aard van die beperkte reg en die belang van sodanige reg vir 'n oop en demokratiese samelewing gebaseer op vryheid en gelykheid;

- $\quad$ die doel waarvoor die reg beperk word en die belang van sodanige doel vir die samelewing; en

- $\quad$ die mate waarin die reg beperk word, die doeltreffendheid van sodanige beperking en in gevalle waar die beperking van 'n reg onafwendbaar is, of die beoogde resultate nie op 'n minder beperkende wyse bereik kan word nie.

4619956 BCLR $665(\mathrm{KH})$ par [104]. 
Alhoewel artikel 36(1) nie uitdruklik melding maak van die belangrikheid van die reg nie, is dit ' $n$ faktor wat in ag geneem moet word by die aanwending van die proporsionaliteitstoets. 'n Afweging van verskillende belange moet steeds plaasvind. Aan die een kant is daar die reg waarop daar inbreuk gemaak word; die aard daarvan; die belang daarvan in ' $n$ oop en demokratiese samelewing gebaseer op menswaardigheid, gelykheid en vryheid; en aan die anderkant die aard en omvang van die beperking. Die afwegingsprosedure en die evaluering van proporsionaliteit moet gekenmerk word deur die oorweging van die verhouding tussen die beperking en die doel daarvan sowel as die aanwesigheid, al dan nie, van ' $n$ minder beperkende wyse om dieselfde doel te bereik.

Die regte van kinders word in artikel 28 uiteengesit. Artikel 28 lui soos volg:

(1) Elke kind het die reg -

(a) op 'n naam en nasionaliteit vanaf geboorte;

(b) op gesinsorg of ouerlike sorg, of op gepaste alternatiewe sorg wanneer die kind uit die gesinsomgewing weggeneem word;

(c) op basiese voeding, skuiling, basiese gesondheidsorgdienste en maatskaplike dienste;

(d) om teen mishandeling, verwaarlosing, misbruik of vernedering beskerm te word;

(e) om teen uitbuitende arbeidspraktyke beskerm te word;

(f) om nie verplig of toegelaat te word om werk te verrig of dienste te lewer nie wat -

(i) onvanpas is vir 'n persoon van daardie kind se ouderdom; of

47 The National Coalition for Gay and Lesbian Equality v The Minister of Justice 19981 BCLR 1517 (KH) par [34].

48 The National Coalition for Gay and Lesbian Equality v The Minister of Justice 19981 BCLR 1517 $(\mathrm{KH})$ par [35]. 
(ii) 'n risiko vir die kind se welsyn, opvoeding, liggaamlike of geestelike gesondheid of geestelike, morele of sosiale ontwikkeling inhou;

(g) om nie aangehou te word nie, behalwe as laaste uitweg, in watter geval, benewens die regte wat 'n kind kragtens artikels 12 en 35 geniet, die kind slegs vir die kortste gepaste tydperk aangehou mag word, en die reg het om -

(i) afsonderlik van aangehoudenes bo die ouderdom van 18 jaar aangehou te mag word; en

(ii) op 'n wyse behandel te word, en in omstandighede aangehou te word, wat met die kind se ouderdom rekening hou;

(h) om, in siviele verrigtinge wat die kind raak, deur die staat op staatskoste van 'n regspraktisyn voorsien te word indien dit andersins tot wesenlike onreg sou lei; en

(i) om nie regstreeks in gewapende stryd gebruik te word nie, en om in tye van gewapende stryd beskerm te word.

(2) ' $\mathrm{n}$ Kind se beste belang is van deurslaggewende belang in elke aangeleentheid wat die kind raak.

(3) In hierdie artikel beteken "kind" iemand onder die ouderdom van 18 jaar.

Dit blyk dat die basis vir die grondwetlike beskerming van die regte van kinders in die lig van veral die grondwetlike waardes van menswaardigheid en vryheid, uitgelê moet word. Vir die doeleindes van die reg van die homoseksuele ouer om beheer en toesig oor 'n kind te verkry, is veral subartikels 1(b), 1(d) en 2 van belang. Subartikel 1(b) handel oor die kind se reg op sorg. Subartikel 1 (d) stel dat 'n kind die reg het om teen vernedering beskerm te word en subartikel 2 bevestig dat die beste belang van die kind die kriterium is wat aangewend word in elke aangeleentheid wat die kind raak. Dit blyk dus duidelik, wat ook al die uitslag van ' $n$ beheer en toesig bevel is, die kind geregtig is op gesinsorg of ouerlike sorg wat gepaard gaan met die afwesigheid van vernedering. Die toekenning van beheer en toesig sal egter moet geskied met duidelike oorweging van die beste belang van die kind. Subartikel 2 stel dit duidelik dat hierdie kriterium die deurslaggewende faktor is in elke aangeleentheid wat die kind raak. 
$\mathrm{Na}$ aanleiding van die voorafgaande is die vraag of daar ooit ' $\mathrm{n}$ belange afweging sal geskied tussen 'n persoon wat aanspraak maak op die reg van gelykheid, in casu die homoseksuele ouer, en die kind wie se beste belang in elke aangeleentheid die deurslaggewende faktor sal wees. Die kind se belange sal altyd voorkeur bo die regte van 'n homoseksuele ouer verkry indien daar bewys kan word dat die optrede van sodanige ouer nie in die beste belang van die kind is nie.

Lind $^{50}$ argumenteer dat daar in die familiereg twee wyses is waarop daar met seksuele oriëntasie omgegaan kan word. Die eerste is dat seksuele oriëntasie 'n relevante oorweging is om enige beslissing wat homoseksuele persone as verskillend tipeer, te regverdig. Die "verskille" tussen homoseksuele - en heteroseksuele persone regverdig dat daar "ongelyk" teenoor eersgenoemde opgetree word. Homoseksuele persone (en biseksuele -) verskil van heteroseksuele persone juis op grond van hul seksuele oriëntasie weens hul geneigdheid om emosioneel en fisies met persone van dieselfde geslag te bind. Dit word as 'n relevante oorweging gebruik om regsreëls wat ongelykheid as ondertoon het te regverdig, terwyl dit benadelend diskriminerend is. Hierdie diskriminerende optrede kan tans deur die Konstitusionele Hof bevraagteken word. In die tweede geval word seksuele oriëntasie geag 'n irrelevante oorweging te wees binne die grense van die familiereg. Die vraag is dus of die seksuele oriëntasie van ' $n$ ouer enigsins in ag geneem behoort te word by die toekenning van beheer en toesig. Daar word voorgestel dat die seksuele oriëntasie van 'n ouer wel in ag geneem behoort te word in dié mate wat daar aangetoon kan word dat dit nie in die beste belang van die kind is nie. Dit sal geskied aan die hand van die aanbieding van relevante getuienis. Die blote aanvanklike weiering van die toekenning van beheer en toesig aan 'n homoseksuele ouer op grond van sy of haar seksuele oriëntasie, sal ongrondwetlikheid tot gevolg hê.

49 Kaganas 1994 Acta Juridica 179. 


\section{Regsvergelykende perspektiewe}

Artikel 39(1)(c) van die Grondwet bepaal dat 'n hof, tribunaal of forum buitelandse reg in ag kan neem by die uitleg van die Handves van Regte.

\subsection{Amerikaanse reg}

Die Amerikaanse reg word gekenmerk deur twee benaderingswyses ten opsigte van beheeren toesig-geskille waarby homoseksuele ouers betrokke is. Die eerste benaderingswyse staan bekend as die per se-reël. Hierdie benaderingswyse is veral gebaseer op die inherente immoraliteit van die homoseksuele ouer. Die tweede benaderingswyse staan bekend as die nexus-reël. By die toepassing hiervan word die seksuele oriëntasie van die ouer nie geag per se diskwalifiserend van aard te wees nie, maar moet daar vasgestel word of daar ' $n$ verband tussen die seksuele oriëntasie van die ouer en benadeling teenoor die kind bestaan.

\subsubsection{Die per se-reël}

Die eerste sake beslis deur die Amerikaanse howe met betrekking tot beheer en toesig en homoseksuele ouers, is gekenmerk deur diskriminasie teen die ouers op grond van hul seksuele oriëntasie. Homoseksualiteit is geag per se 'n diskwalifiserende faktor te wees by die toekenning van beheer en toesig. Die leefwyse van homoseksuele persone is gestereotipeer as immoreel. In Schuster $v$ Schuster ${ }^{52}$ het 'n lesbiese paartjie deskundige psigiatriese getuienis aangebied wat daarop gedui het dat die seksuele oriëntasie van die ouers irrelevant is by die ontwikkeling van die kind en dat die kinders in casu gesond en

50 Lind 1995 SALJ 493.

51 Anon (A) 1989 Harv LR 618-619; Anon (B) 1989 Harv LR 1629-1631; Eskridge en Hunter Sexuality $832,836$.

52585 P.2d 130 (Wash.1979) soos aangehaal uit Eskridge en Hunter Sexuality 832. 
normaal is. Beheer en toesig word aan die moeder toegeken onderworpe aan sekere voorwaardes. Die verhoorhof maan die moeder en haar vriendin aan om nie die kinders te "gebruik" as 'n vertoonkas vir homoseksualiteit nie en die appèlhof weier die lesbiese paartjie saamwoonregte. Dit is duidelik dat die werking van hierdie reël gebaseer is op die immoraliteit van homoseksuele oriëntasie.

Verbandhoudend met die werking van die per se-reël is die konserwatiewe benadering wat in state soos Alabama en Florida gevolg word. Wetgewing vereis dat howe die morele welstand van die ouer oorweeg by die toekenning van beheer en toesig. In verskeie ander state word die inagneming van morele welstand as vereiste deur die howe in hul beslissings geïnkorporeer. Howe in Missouri en Virginia ken uit die staanspoor nie beheer en toesig aan 'n homoseksuele ouer toe in die geval waar daar 'n dispuut tussen 'n homoseksuele - en heteroseksuele ouer bestaan nie.

\subsubsection{Die nexus-reël}

Gedurende die sewentigerjare het daar 'n klemverskuiwing plaasgevind deurdat voorsittende beamptes die algehele beste belang van die kind oorweeg het by die toekenning van beheer en toesig in die geval waar een of albei ouers se seksuele oriëntasie homoseksueel was. In Bezio $v$ Patenaude ${ }^{55}$ het die hooggeregshof van Massachusetts beslis dat daar uitdruklik aangetoon moet word dat ' $n$ kind benadeel word waar daar sprake van homoseksualiteit aan die kant van die ouers is en dat algemene kulturele vooroodele nie sodanige benadeling daarstel nie. In Conkel $v$ Conkel het die Ohio appèlafdeling oornagtoegangsregte aan ' $n$ biseksuele vader wat saam met sy vriend gewoon het, toegestaan. Die hof bevestig dat hy nie die ongewildheid van homoseksualiteit in die samelewing as oorweging in ag kan neem, as dit sy plig is om die

53 Eskridge en Hunter Sexuality 832.

54 Eskridge en Hunter Sexuality 837.

55410 N.E.2d 1207 (Mass.1980) soos aangehaal uit Eskridge en Hunter Sexuality 833.

5631 Ohio App.3d 169, 509 N.E.2d 983 (1987) soos aangehaal uit Eskridge en Hunter Sexuality 833 en Anon (B) 1989 Harv LR 1633. 
fundamentele ouer-kind verhouding te beskerm en te laat geld nie. Die hof vervolg deur daarop te wys dat dit nie die taak van die Amerikaanse grondwet is om die vooroordele van die gemeenskap te verdra nie. Hierdie beslissing reflekteer egter 'n relatief neutrale benadering by die toekenning van beheer en toesig; die seksuele oriëntasie van die ouer is hoofsaaklik irrelevant by beheer en toesig beslissings; die enigste relevante faktor is die beste belang van die kind en die sosiale aanvaarbaarheid en houdings ten opsigte van homoseksualiteit is irrelevant by die vasstelling van die beste belang van die kind.

Die relevansie van die beslissing van die Amerikaanse hooggeregshof in Palmore $v$ Sidoti, $^{57}$ alhoewel in die konteks van rassediskriminasie, kan nie ontken word nie. Die hof beslis dat die verandering van beheer en toesig vanaf die blanke moeder (sy het hertrou met 'n swart man) na die vader, gebaseer op moontlike vooroordele van die gemeenskap, diskriminasie daarstel. Die hof erken dat dit die plig van die staat is om toe te sien dat daar omgesien word na die beste belang van die kind en alhoewel die teenwoordigheid van die kind in 'n meerrassige huis sosiale druk vir die kind kan skep, persoonlike vooroordele van die gemeenskap steeds nie diskriminasie regverdig nie.

Howe in die meeste Amerikaanse state volg die sogenaamde nexus-reël. Hierdie reël behels dat daar ' $n$ verband tussen die seksuele oriëntasie van die ouer en benadeling teenoor die kind moet bestaan. State wat hierdie reël volg sluit onder andere Alaska, Kalifornië, Indiana, Massachusettes, New Jersey, New Mexico, New York, Vermont en Washington in. In Birdsall v Birdsall ${ }^{58}$ het die Kaliforniese appèlhof 'n verbod teen 'n gay vader se oornagtoegangsregte in die teenwoordigheid van 'n ander homoseksuele persoon nietig verklaar, op grond van die werking van die nexus-reël. Die hof stel dat:

The unconventional life style of one parent, or the opposing moral positions of the parties, or the outright condemnation of one parent's beliefs by the

57466 U.S. 429, 104 S.Ct. 1879, 80 L.Ed.2d 421 (1984) soos aangehaal uit De Vos 1994 SALJ 693, Eskridge en Hunter Sexuality 831 en Nöthling-Slabbert 1995 CILSA 369.

58243 Cal.Rptr. 287 (Cal.App.1988) soos aangehaal uit Eskridge en Hunter Sexuality 837. 
other parent's religion, which may result in confusion for the child, do not provide an adequate basis for restricting visitation rights. Evidence of one parent's homosexuality, without a link to detriment to the child, is insufficient to constitute harm.

\subsubsection{Die beste belang van die kind}

By die bepaling van die beste belang van die kind gebruik die meeste state vergelykbare kriteria in geval van beheer en toesig aangeleenthede. Voorsittende beamptes beskik egter oor 'n wye diskresie by die keuse van relevante faktore.

Die Uniform Marriage and Divorce Act, aangeneem in verskeie Amerikaanse state, lys vyf faktore wat in ag geneem behoort te word by die toekenning van beheer en toesig oor 'n kind, maar dit laat ook ruimte vir die inagneming van ander relevante faktore:

- $\quad$ die wense van die ouers om wie die beheer en toesig aansoek draai;

- $\quad$ die wense van die kind;

- $\quad$ die verhouding tussen die kind en sy/haar ouer/s;

- die aanpassing van die kind in sy/haar huis, skool en gemeenskap; en

- $\quad$ die geestes- en fisiese gesondheid van al die partye betrokke.

Kinders word gewoonlik geplaas in 'n omgewing waar hulle die meeste stabiliteit geniet en sorg ontvang. Ander faktore wat in ag geneem word is die optrede van die ouers, die finansiële status en lewenstyl van die partye, ras, kleur, nasionaliteit, politieke affiliasie, geslag en seksuele oriëntasie.

\subsubsection{Wetgewende en grondwetlike beperkings}

59 Eskridge en Hunter Sexuality 836-837.

60 9A ULA 96198 (1979) soos aangehaal uit Nöthling-Slabbert 1995 CILSA 368. 
Die howe gebruik verskeie faktore om aan te toon dat beheer en toesig oor ' $n$ kind of toegang tot 'n kind aan 'n homoseksuele ouer, die kind nadelig sal raak. Hierby ingesluit is onder andere die teistering of stigmatisering van die kind, die beïnvloeding van die seksuele oriëntasie van die kind, die benadeling van die morele welsyn van die kind, die moontlikheid van seksuele molestering en die plig wat sodomie-wetgewing op die staat plaas om te waak teen homoseksualiteit en sodomie.

Hierdie faktore is nie vry van kritiek nie. Ten opsigte van die teistering van die kind bestaan daar slegs een gerapporteerde geval in die Amerikaanse geskiedenis. By wyse van psigoseksuele - en psigometriese studies is daar aangetoon dat homoseksuele ouers se kinders nie meer geneig is tot homoseksualiteit as die kinders van heteroseksuele ouers nie. Wat die morele welsyn van die kind betref, word daar opgemerk dat dit nie dieselfde beteken as die beste belang van die kind nie. Daar word aangevoer dat dit slegs moontlik is om te spekuleer welke seksuele oortuiging die beste vir die kind is. Voorsittende beamptes moet waak teen 'n refleksie van hul persoonlike morele oortuigings in hul uitsprake. Ten opsigte van seksuele molestering toon studies aan dat die meeste kindermolesteerders heteroseksuele mans is. ${ }^{63}$ Verder word daar gewys op die onderskeid tussen sodomie en homoseksualiteit, elk 'n verskynsel met 'n eie bestaansreg wat soms wel saam bestaan. ${ }^{64}$ In die meeste gevalle waar die howe homoseksuele ouers beheer en toesig oor ' $n$ kind geweier het, is geen getuienis aangaande sodomie gelei nie.

Die staat moet die beste belang van die kind ten alle tye as bepalende faktor in ag neem by beheer en toesig - en toegangsaangeleenthede. Ander staatsbelange geniet gevolglik sekondêre aandag. Indien sodanige beslissings slegs gebaseer is op die seksuele oriëntasie van die ouer/s, sal dit neerkom op diskriminasie op grond van seksuele oriëntasie. ${ }^{66}$ Die

61 Nöthling-Slabbert 1995 CILSA 368.

62 Anon (A) 1989 Harv LR 620; Anon (B) 1989 Harv LR 1637-1638.

63 Anon (B) 1989 Harv LR 1638-1640.

64 Anon (A) 1989 Harv LR 625.

65 Anon (B) 1989 Harv LR 1640.

66 Anon (A) 1989 Harv LR 626-630; Anon (B) 1989 Harv LR 1640-1641. 
weiering van beheer en toesig oor 'n kind en toegang tot 'n kind op grond van die seksuele oriëntasie van die ouer maak verder ook inbreuk op die reg van intieme assosiasie. Alhoewel daar geen uitspraak gerapporteer is waarin die omvang van sodanige reg as sulks aangetoon is nie, word daar algemeen aanvaar dat dit stilswyend grondwetlike beskerming geniet. $^{67}$ 'n Poging van die staat om 'n kind se eie seksuele oriëntasie te beskerm teen homoseksualiteit of die beskerming van die morele welsyn van die kind teen homoseksualiteit, is onwettig aangesien dit direk of indirek afhanklik is van 'n bedoeling ten gunste van 'n beskermde klas. Verdere inbreukmaking geskied ook ten opsigte van die prosessuele regte van die homoseksuele ouer aangesien hy/sy dikwels nie voldoende geleentheid gebied word om 'n saak uit te maak nie.

\section{2 'n Engelsregtelike perspektief}

Boyd $^{69}$ argumenteer die kwessie van beheer en toesig en homoseksuele ouerskap aan die hand van die familiefiguur met spesifieke verwysing na $C \vee C{ }^{70}$ 'n Engelsregtelike appèlhofbeslissing in hierdie verband.

\subsubsection{C v C}

In casu moes die appèlhof beslis oor die toekenning van beheer en toesig oor 'n sewejarige dogter. Die dogter het bykans sewe jaar by haar moeder gebly. Gedurende hierdie tydperk was die moeder die primêre figuur in haar lewe, soos opgemerk deur die verhoorhof. Die vader en moeder het vir 'n jaar en 'n half saamgewoon in Shrewsbury, waarna die vader uitgetrek het en die moeder om 'n egskeiding gedagvaar het. Die dagvaarding het 'n voorstel van gesamentlike beheer en toesig oor die kind (C) ingesluit. Hierby inbegrepe was die toekenning van beheer en toesig aan die moeder en redelike toegangsregte aan die vader.

67 Anon (A) 1989 Harv LR 624.

68 Anon (B) 1989 Harv LR 1641-1642.

69 Boyd 1992 MLR 269-278.

70 (A Minor) (Custody Appeal) [1991] Family Law Reports No3 223 soos aangehaal uit Boyd 1992 MLR 270. 
Die dagvaarding is nie deur die moeder geopponeer nie. Tydens die egskeidingsgeding het daar 'n dispuut ten opsigte van die beheer en toesig oor die kind ontstaan. Die moeder was 'n amptenaar in diens van korrektiewe dienste en sy is verplaas na Staffordshire. Die kind het saam met haar moeder verhuis en daar is ooreengekom dat C onder die beheer en toesig van haar moeder sou bly, terwyl die vader redelike toegangsregte geniet het." Gedurende die dienstydperk van die moeder as gevangenisamptenaar, het sy 'n lesbiese verhouding met 'n kollega aangekoop. Die moeder het ook 'n verhouding met een van die vroulike gevangenes, A, aangeknoop. By A se vrylating het sy by die moeder en $C$ ingetrek. Hierdie gebeure het geen reaksie van die vader uitgelok nie, tot en met een van $C$ se besoeke aan haar vader (hy het in die tussentyd hertrou) bykans ses maande later. Gedurende hierdie besoek doen die vader aansoek vir beheer en toesig oor C en verkry hy 'n tussentydse bevel vir beheer en toesig.

Die beslissing van die verhoorhof in die guns van die moeder is gebaseer op die getuienis van 'n maatskaplike werker, die ouers en hul onderskeie metgeselle. Die maatskaplike werker het getuig dat beide ouers se optrede gerig is op C se welsyn en dat beide ouers 'n liefdevolle verhouding met $\mathrm{C}$ het en dat $\mathrm{C}$ gelukkig in beide huise sal wees. Die verhoorhofregter was egter van mening dat indien hy sou kon kies tussen 'n heteroseksuele lewenstyl en 'n homoseksuele lewenstyl, hy die "normale" sou verkies. Hy merk egter op dat 'n keuse nie so eenvoudig is nie. Indien die vader beheer en toesig oor C sou kry, sou sy steeds blootgestel wees aan haar moeder se lesbiese verhouding vanweë die moeder se toegangsregte. Gevolglik beslis die regter in guns van die moeder en veral ook vanweë die sterk band tussen $\mathrm{C}$ en haar moeder.

Op appèl het die hof beveel dat 'n herverhoor gehou moes word. Die primêre saak onder bespreking was die lesbiese verhouding van die moeder. Beide regters op appèl was versigtig om op te merk dat die moeder se lesbiese verhouding bepalend was in die

71 Boyd 1992 MLR 270.

72 Boyd 1992 MLR 270.

73 Boyd 1992 MLR 270-271. 
beslissing teen haar. Daar word opgemerk dat solank 'n heteroseksuele vader huislike omstandighede verskaf wat as "normaal" beskou kan word, dit moeilik sal wees vir 'n lesbiese moeder om beheer en toesig oor 'n kind te kry, veral weens die ooglopende voortsetting van sodanige verhouding.

\subsubsection{Die "normale" gesin}

In $C$ v $C$ kon die vader deur middel van hertroue 'n heteroseksuele gesin rekonstrueer. Alhoewel beide die vader en die stiefmoeder werk, het laasgenoemde, 'n verpleegster, haar skofte só beplan dat òf sy, òf die vader, C daagliks skool toe kon neem en haar weer gaan haal. Die verhoorhofregter beskryf sy dilemma om te kies tussen die twee ouers as 'n belange-afweging tussen 'n vader wat in 'n klassieke man-en-vrouverhouding leef en 'n moeder wat altyd nog die primêre figuur in C se lewe was. Boyd verwys na Julia Brophy wat opmerk dat dit dikwels die geval by lesbiese beheer- en toesig-geskille is dat regters eerder fokus op die vrou se seksuele gedrag as op die welsyn en primêre sorg van die kind. ${ }^{74}$ Regter Glidewell se opmerking rondom die klassieke heteroseksuele huwelik veronderstel dat 'n huis slegs liefdevol, versorgend en sensitief kan wees indien dit gekonstitueer word deur heteroseksuele lede wat verkieslik getroud is. Daar kan saam met Boyd gestem word dat hierdie definisie 'n diversiteit gesinsvorme ontken, byvoorbeeld enkelouerfamilies en oënskynlik "normale" heteroseksuele gesinne wat geteister word deur gesinsgeweld en ander maatskaplike euwels. Sy voer verder aan dat dit makliker vir mans is om 'n "ideale" gesin aan 'n hof voor te hou, aangesien mans meer geneig is tot hertroue as vrouens.

Alhoewel regter Balcombe opmerk dat 'n voorsittende beampte se eie morele oortuigings en subjektiewe vooroordele geen rol behoort te speel nie, meen hy tog dat 'n regter wel sy/haar ervaring mag gebruik om te bepaal wat aanvaarbare standaarde is aangesien hierdie nie 'n geval van 'n spesifieke etniese minderheid is nie. 
Boyd argumenteer dat ' $n$ regter die morele standaarde wat geld in ' $n$ gemeenskap waarin die welsyn van die kind bevorder word, as vertrekpunt moet gebruik. Beide regters Balcombe en Glidewell is egter van mening dat ' $n$ kind grootgemaak moet word in ' $n$ huis met ' $n$ vader en ' $n$ moeder. Indien dit onmoontlik is moet daar gestreef word na omstandighede wat naby aan bogenoemde norm is. Regter Balcombe is van mening dat die fout wat deur die verhoorhof gemaak word, is om nie ' $n$ heteroseksuele gesin as vertrekpunt te gebruik nie.

Die appèlhofbeslissing in $C v C$ is ' $n$ weerspieëling van die plek wat die heteroseksuele gesin in die Engelse familiereg inneem, veral ook met verwysing na beheer en toesig oor ' $n$ kind. Sodoende word die bestaan, potensiaal en vermoë van ander gesinsvorme ontken. Boyd voer aan dat die ontwikkeling van 'n gesinsvorm as standaard nie opsigself vatbaar vir kritiek is nie, solank sodanige standaard sensitief is vir ander ideologieë en vorme wat op grond van ras, klas en seksuele oriëntasie verskil.

\section{$4 \quad$ Gevolgtrekking}

Die insluiting van ' $n$ Handves van Regte in die Grondwet gee aanleiding tot die grondwetlike beskerming van spesifieke regte, inbegrepe die reg op gelykheid, by implikasie homoseksuele oriëntasie, en die regte van kinders. Die uitleg van hierdie regte moet geskied aan die hand van die grondwetlike waardes van menswaardigheid in die besonder, maar ook gelykheid en vryheid. Hierdie regte geniet egter nie absolute gelding nie en gevolglik sal daar oorweging aan die inhoud van artikel 36 van die Grondwet gegee moet word. Daar kan met gesag geargumenteer word dat die beste belang van die kind die deurslaggewende kriterium is by die toekenning van beheer en toesig. Indien dit egter sou blyk dat die regte van 'n homoseksuele ouer en dié van 'n kind in konflik is, sou daar aan sodanige kriterium gevolg gegee moet word. Hierdie argument regverdig nie per se diskriminasie teen 'n homoseksuele ouer op grond van sy/haar seksuele oriëntasie 
76 Boyd 1992 MLR 273.

77 Boyd 1992 MLR 277. 
nie. Die aanwesigheid van 'n verband tussen die homoseksuele oriëntasie van die ouer en benadeling teenoor die kind, sal die enigste regverdigingsgrond wees vir die weiering van beheer en toesig aan 'n homoseksuele ouer. $\mathrm{Na}$ aanleiding van die vooraf geargumenteerde is dit my submissie dat die bewys van benadeling, weens die homoseksuele oriëntasie van die ouer, teenoor die kind moeilik sal geskied. Voorsittende beamptes moet waak daarteen om hul eie moraliteit en vooroordele af te druk op beheer en toesig bevele rakende homoseksuele ouers; ander dissiplines buiten die reg, byvoorbeeld die sielkunde en sosiologie, moet ingespan word om te bepaal wat die beste belang van die kind in 'n spesifieke geval is; en howe moet steeds op hul objektiewe kennis en wysheid steun in gevalle waar getuienis onvolledig en sinloos is.

Die vasstelling van die beste belang van die kind en die toekenning van beheer en toesig oor 'n kind, spesifiek met verwysing na die homoseksuele ouer, is emosioneelkontroversieel gekompliseerd. Die aanwesigheid van meer as een belangegroep aan wie se fundamentele regte daar gevolg gegee moet word kompliseer die situasie. Die situasie mag dus voordoen waar daar nie uitdrukking aan al die betrokkenes se regte gegee kan word nie, in welke geval die beste belang van die kind voorkeur sal geniet. 


\section{Bibliografie}

Anon 1989 Harv LR

Anon "Custody denials to parents in same-sex relationships: an equal protection analysis" 1989 Harv LR 617-636

Anon 1989 Harv LR

Anon "Sexual orientation and the law" 1989 Harv LR 1508-1671

Barnard Cronjé en Olivier Persone- en Familiereg

Barnard AH Cronjé DSP en Olivier PJJ Die Suid-Afrikaanse Persone- en Familiereg (Butterworths Durban 1994)

Bonthuys 1994 Stell LR

Bonthuys E "Awarding access and custody to homosexual parents of minor children: a discussion of Van Rooyen v Van Rooyen 19942 SA 325 (W)" 1994 Stell LR 298313

Boyd 1992 MLR

Boyd SB "What is a 'normal' family? C v C (A Minor) (Custody Appeal)" 1992 Modern Law Review 269-278

Brits 1994 THRHR

Brits JJ "Toegang tot kinders, lesbianisme en die Konstitusie" 1994 THRHR 710-712

Cameron 1993 SALJ

Cameron E "Sexual orientation and the Constitution: a test case for human rights" 1993 SALJ 450-472 
Clark 1998 CILSA

Clark B "Competing custody rights: new concepts of 'family' and the best interests of the child" 1998 CILJSA 288-306

Cronjé en Heaton Vonnisbundel

Cronjé DSP en Heaton J Vonnisbundel oor die Persone- en Familiereg/Casebook on the Law of Persons and Family Law (Butterworhs Durban 1994)

De Vos 1994 SALJ

De Vos $P$ "The right of a lesbian mother to have access to her child" 1994 SALJ 687694

De Vos 1996 THRHR

De Vos $\mathrm{P}$ "Seksuele georiënteerdheid en die familiereg: reaksie op PJ Visser" 1996 THRHR 304-308

\section{Eskridge en Hunter Sexuality}

Eskridge WN (Jnr) en Hunter ND Sexuality, Gender and the Law (The Foundation Press Inc New York 1997)

Hahlo Husband and Wife

Hahlo HR The South African Law of Husband and Wife (Juta Kaapstad 1985)

Henderson 1997 SALJ

Henderson AJH "Cry, the beloved Constitution? Constitutional amendment, the vanished imperative of the constitutional principles and the controling values of section 1" 1997 SALJ 542-555

Hoffman en Pincus Custody

Hoffman A en Pincus BK The Law of Custody (Butterworths Durban 1989) 
Kaganas 1994 Acta Juridica

Kaganas F "Joint custody and equality in South Africa" 1994 Acta Juridica 169-184

Lambiase en Cumes 1987 SALJ

Lambiase EEA en Cumes JW "Do lawyers and psychologists have different perspectives on the criteria for the award of custody of a child?" 1987 SALJ 704-708

\section{Lind 1995 SALJ}

Lind C "Sexual orientation, family law and the transitional Constitution" 1995 SALJ 481-502

Mosikatsana 1996 Acta Juridica

Mosikatsana TL "Gay/Lesbian adoptions and the best interests standard: a critical analytical perspective" 1996 Acta Juridica 114-132

Nöthling-Slabbert 1995 CILSA

Nöthling-Slabbert $M$ "Child custody and race in the light of the new South African Constitution: a comparative approach" 1995 CILSA 361-382

\section{Palmer 1996 Acta Juridica}

Palmer A "The best interests criterion: an overview of its application in custody decisions relating to divorce in the period 1985-1995" 1996 Acta Juridica 98-113

\section{Robinson 1995 THRHR}

Robinson JA "Die beste belang van die kind by egskeiding: enkele gedagtes na aanleiding van McCall v McCall 19943 SA 201 (K)" 1995 THRHR 472-478

\section{Robinson 1995 THRHR}

Robinson JA "Inleiding tot die familiereg/Introduction to family law/Family law: cases and materials" 1995 THRHR 755-759 
Robinson 1989 TRW

Robinson JA "'n Oorsig oor die vertrekpunte van die Engelse Children Act van 1989" 1993 TRW 41-66

Steyn 1998 TSAR

Steyn E "From closet to constitution: the gay family rights odyssey" 1998 TSAR 97117

Van der Linde 1995 Codicillus

Van der Linde S (Vonnisbespreking) McCall v McCall 19943 SA 201 (K) 1995 Codicillus 63-64

Visser 1995 THRHR

Visser PJ "Enkele gedagtes oor fundamentele regte en die familiereg" 1995 THRHR 702-708

Wolhuter 1997 SALJ

Wolhuter L "Equality and the concept of difference: same-sex marriages in the light of the final Constitution" 1997 SALJ 389-411

\section{Lys van Wetgewing}

Engelse Children Act van 1989

Grondwet van die Republiek van Suid-Afrika 200 van 1993

Grondwet van die Republiek van Suid-Afrika 108 van 1996

Uniform Marriage and Divorce Act 9A ULA 96198 (1979)

Wet op Bemiddeling in Sekere Egskeidingsgedinge 24 van 1987

Wet op Egskeiding 70 van 1979 


\section{Register van Hofsake}

Bezio v Patenaude 410 N.E.2d 1207 (Mass.1980)

Birdsall v Birdsall 243 Cal.Rptr. 287 (Cal.App.1988)

C v C (A Minor) (Custody Appeal) [1991] Family Law Reports No 3223

Conkel v Conkel 31 Ohio App.3d 169, 509 N.E.2d 983 (1987)

Harksen v Lane NO and Others 199711 BCLR 1481 (KH)

Märtens v Märtens 19914 SA 287 (T)

McCall v McCall 19943 SA 201 (K)

The National Coalition for Gay and Lesbian Equality and Others $v$ The Minister of Justice and Another 19981 BCLR $1517(\mathrm{KH})$

Palmore v Sidoti 466 U.S. 429, 104 S.Ct. 1879, 80 L.Ed.2d 421 (1984)

S v H 1993 SAS 545 (K)

$S$ v Makwanyane and Another 19956 BCLR $665(\mathrm{KH})$

S v S 19932 SA 200 (W)

Schuster v Schuster 585 P.2d 130 (Wash.1979)

Segal v Segal 19714 SA $317(\mathrm{~K})$

September v Karriem 19593 SA 687 (K)

Van Rooyen v Van Rooyen 19942 SA 325 (W) 